\title{
画像範囲値を用いた同質領域判定手法による シイ・カシ萌芽林とスギ・ヒノキ人工林の樹冠抽出
}

The Analysis of Forest Crowns by Same-Color-Region Determining Method Utilized Image Range Features of Castanopsis cuspidata Coppice Woodland and Cryptomeria japonica and Chamaecyparis obtusa Artificial Forest

朝廣 和夫* 井上 光平 ${ }^{* *}$ 重松 敏則* 瀬戸島政博*** Kazuo ASAHIRO Kouhei INOUE Toshinori SHIGEMATSU Masahiro SETOJIMA

Abstract : This research attempted to reveal that utilization of aerial photograph's image range feature for classification of forest crowns by Same-Color-Region Determining Method of Castanopsis cuspidate coppice woodland and Cryptomeria japonica and Chamaecyparis obtusa artificial forest in northern part of Kyusyu, Japan. This research consist from two parts, one is the method improving applied by image range features such as standard deviation and cumulative frequency of tree crown edge for parameter setting. And the other is crown width classification accuracy was proved by field survey data of each tree crowns. As a results, supervised classifications of this improved method were capable of correctly classifying coppice woodland canopies with radii greater than $1.5 \mathrm{~m}(\mathrm{r}< \pm 1.0 \mathrm{~m})$ to an accuracy of $34.4 \%$. For artificial forest, $41.4 \%$ of trees with tree crown radii greater than $1.0 \mathrm{~m}(\mathrm{r}< \pm 0.5 \mathrm{~m})$ could be correctly classified.

Keywords: Tree crown, Aerial photography, Image processing, Forest environment, Photogrammetry キーワード：樹冠，航空写真，画像解析，森林環境，写真測量

\section{1.はじめに}

景観の保全による農村振興やまちづくりは，持続的な農林業や 生物多様性など，いわゆるアメニティを維持する上で強化されな ければならない課題である。このような地域環境保全に資する環 境調査の分野において，昨今, GIS やリモートセンシングによる 情報利用が進められている。森林環境においては, 二酸化炭素の 吸収源として期待されている一方で，スギ・ヒノキ人工林の未間 伐などによる風倒木被害に加え, 皆伐放棄地問題が顕在化してい る。里山林においては生産に見合わない竹林や雑木林の薮化が数 多く報告されて久しい。これらの実態を適切な環境管理や環境教 育, 環境計画につなげるには, モザイク状に分布し成長する森林 環境の動態を詳細に把握する必要がある。昨今の森林測量の研究 では, 航空写真に加え衛星画像やレーザープロファイラを用いた デジタルデータを用い, 樹種構成や樹林高, そして立木密度に関 する研究が進められている。本論は，その中でも研究事例の少な い広葉樹林の樹冠解析手法の開発に着目した研究である。

森林の空撮画像より樹冠円を抽出・描画する 1 手法として，小 村ら（2001）の同質領域判定手法が報告されている ${ }^{1)}$ 。小村ら （2003）はフラクタル次元による改善を考案し ${ }^{2)}$ ，井上ら（2006） はその手法を用いた多重オルソフォト画像による解析法の研究を 展開している ${ }^{3)}$ 。一方, 当初の方法 ${ }^{1)}$ の研究展開として, 朝廣ら （2003）は九州北部里山林において追試を行い，ほぼ同様の結果 を得ており，重なり円等の咒長情報の除去方法を開発した ${ }^{4}$ 。し かしながら, 同方法は空中写真画像の画素值を同質と判定する輝 度值の範囲（以下，判定基準值という。）をパラメータとして画 素ごとに設定する必要があり, 適切に樹冠幅を抽出し得る自動処 理方法の開発が課題とされた。

本論は, 九州北部に分布するシイ・カシ萌芽林およびスギ・ヒ ノキ人工林を対象とし, この同質領域判定手法について, 画像範 囲值を用いた画素毎のパラメー夕の設定方法を考案した。さらに， 解析結果を本対象地の林分を用いて検証を行い，モデルの機能性
と本対象地における精度を明らかにすることを目的とした。

\section{2. 調查対象地と解析方法}

\section{(1) 調査対象地の設定}

本調查解析に用いる対象地は, 主にシイ・カシ萌芽林とスギ・ ヒノキ人工林の分布する福岡県福岡市北西の新宮町的野地区の私 有林である。ここは，標高 50 200mの比較的急峻な丘陵地に位 置し，土壌は受蝕土である。森林の多くは，かつて薪の採取など に利用されており，1960 年代，もしくはそれ以前から管理放棄 されたり，スギ・ヒノキの植林が行われてきた。本論では，下記

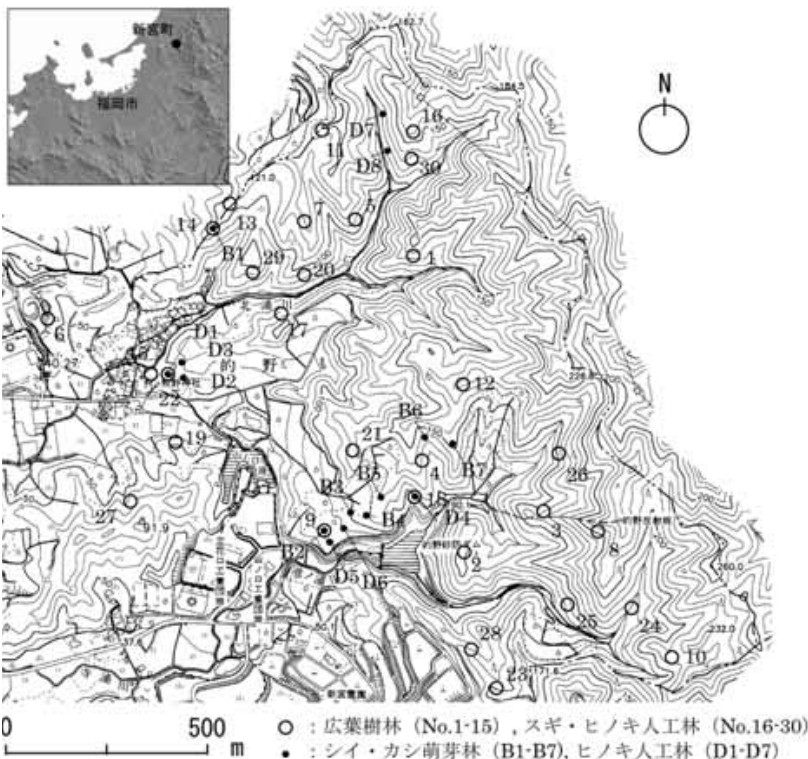

図-1 調查対象地位置図

*九州大学大学院芸術工学研究院環境計画部門 ${ }^{* *}$ 九州大学大学院芸術工学研究院視覚情報部門 ${ }^{* * *}$ 社団法人日本測量協会 
の理由により 2 つの調査区群を用いることとした。

まず，同質領域判定手法の改良については，先に報告し た ${ }^{4)}$ と同じデー夕を用いる。この調査区は広葉樹林とスギ・ ヒノキ林という相観植生に分け，それぞれ 15 区ずつ，合 計 30 の調査区からなる(図一 1 , 図一 2 : カラーページ)。 調査区の設定は空撮画像の目視判読により画像が明瞭で, 十分な樹冠数を含む面積を有し，そして，若齢から壮齢ま で含む樹冠幅階の異なる調查区である。同デー夕を用いる ことにより先の解析結果と比較考察できるようにした。次 に，樹木毎の検証については先に報告した ${ }^{5)}$ と同じデータ を用いる。設定した調査区数は，シイ・カシ萌芽林 7 調査 区，ヒノキ人工林 7 調查区である（図 -1 , 図 -2 )。検 証ではスギ人工林よりも林冠閉鎖度の高いヒノキ人工林を 扱い，スギ人工林は今後の課題とした。

それぞれの林分構造および種組成については引用論文に 報告されている。本論に扔いて広葉樹林とスギ・ヒノキ人 工林を一括して扱う理由は, 森林の空撮画像を用いた面的 な解析アルゴリズムの開発を目的としているからである。 植生の違いによる解析結果への影響については，考察の中 で個々に取り扱いを行う。

\section{(2) 解析に用いた空撮画像}

解析に用いたカラー航空写真は, 1999 年 5 月 12 日に撮 影（撮影縮尺：約 1/10,000）したもので，常緑広葉樹の 開花・新葉の美しい時期である。これをデジタル画像に変 換し, 数值地図 $50 \mathrm{~m}$ メッシュ標高デー夕（財団法人日本 地図センター発行）を用いて, 中心投影の航空写真画像から正射 投影画像（オルソ画像）を作成した。本研究に使用した空撮画像 （図－2）はRGB256 階調で, 地上解像度 $45 \mathrm{~cm}$ に処理したデー夕 である。

\section{（3）同質領域判定手法の改良}

同質領域判定手法の考え方は, 小村ら $(2001)^{11}$, 朝廣ら (2003) の報告と同様であるが，その解析方法を下記に示す。

この処理方法は, 1 つの画素 $p$ に注目し, $p$ の RGB 值を $R$, $G, B$ とする。また $p$ を中心とする半径 $\mathrm{r}$ の円を考え, 円内のあ る画素 $p^{\prime}$ の RGB 值を $R^{\prime}, G^{\prime}, B^{\prime}$ とする。このとき輝度值の許容 範囲, いわゆる判定基準值 $h$ を設定して $\left|R-R^{\prime}\right|<h$ かつ $\mid G-G$, $\mid<h$ かつ $\left|B-B^{\prime}\right|<h$ ならば $p^{\prime} は$ と $p$ 同質とする。円内の全ての 画素 $p$ ’が中心画素 $p$ と同質ならばその円を同質領域とする。 円の半径を徐々に大きくしながら同質領域円の半径の最大值を求 める。以上を全ての画素について行う。そうすると各画素に同質 領域円の半径の最大值が格納された円半径分布算出結果が得られ る(図ー3: カラーページ)。

この円半径分布算出結果画像の大きな円の内部には, 小さな円 が多数含まれている。これをて長情報として取り除く。まず最大 の半径をむつ画素を探し出し, その円内に含まれる他の円を取り 除く。次に残った円の中から半径が最大のものを探し出し, その 円内に含まれる他の円を取り除く。このような操作を半径の最大 值が $45 \mathrm{~cm}$ (1 画素) になるまで繰り返す。除去されずに残った 円の位置を点で表示したものがこ長情報除去結果である。樹冠抽 出結果の画像として, 各円の内部を中心の画素の色で塗りつぶし て円の位置, 大きさ, 色を 1 つの画像に表示した再構成画像を作 成した。

先の研究では ${ }^{4)}$, 判定基準値 $\mathrm{h}$ を $15 \sim 60$ 階調の範囲で解析を 行ったところ, 各調查区には誤差率 0 となる判定基準值が存在し, 広葉樹林は h:28〜 45 階調, スギ・ヒノキ林は h:17〜32 階調であっ た。そして, これを推定誤差率 $0 \%$ の判定基準值 h' と定義し, h' は樹冠サイズの違いにより変化することを明らかにした。また， 後の研究では ${ }^{5)}$, ヒノキ人工林だけであるが, 画素值の標準偏差
表－1 回帰式および 95\%信頼区間の上下式による推定測定基準値と 樹冠径誤差率

\begin{tabular}{|c|c|c|c|c|c|c|c|c|c|c|c|c|c|c|c|c|}
\hline No. & 1 & 2 & 3 & 4 & 5 & 6 & 7 & 8 & 9 & 10 & 11 & 12 & 13 & 14 & 15 & 平拈 \\
\hline 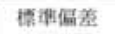 & 25 & 26 & 29 & 32 & 23 & 24 & 27 & 29 & 30 & 24 & 25 & 30 & 24 & 46 & 18 & B \\
\hline $\mathrm{h}^{*}$ & 30 & 27 & 37 & 46 & 31 & 32 & 32 & 37 & 49 & 49 & - & - & - & - & - & \\
\hline 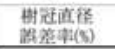 & -2 & -1 & -1 & -1 & -1 & -1 & 0 & 0 & -2 & 2 & - & - & - & - & - & $-1 \%$ \\
\hline$\hat{\mathrm{h}}$ & 35 & 36 & 40 & 44 & 32 & 34 & 37 & 39 & 41 & 34 & 35 & 41 & 33 & 60 & 27 & \\
\hline 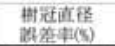 & 9 & 30 & 6 & -3 & 1 & 8 & 11 & 3 & -23 & -41 & .45 & -50 & -43 & -37 & -54 & $0 \%$ \\
\hline 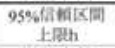 & 38 & 39 & 44 & 49 & 35 & 36 & 41 & 43 & 46 & 37 & 38 & 45 & 36 & 73 & 30 & \\
\hline 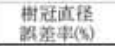 & 15 & 27 & 36 & 8 & 11 & 23 & 21 & 14 & -10 & -38 & -43 & -44 & -40 & .36 & -49 & $11 \%$ \\
\hline 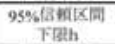 & 33 & 33 & 36 & 39 & 30 & 31 & 34 & 36 & 37 & 31 & 32 & 37 & 31 & 47 & 25 & \\
\hline 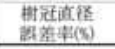 & 4 & 21 & -5 & -11 & -5 & -3 & 4 & .9 & -28 & .47 & -52 & -54 & -46 & .46 & -63 & $.8 \%$ \\
\hline No. & 16 & 17 & 18 & 19 & 20 & 21 & 22 & 23 & 24 & 25 & 26 & 27 & 28 & 29 & 30 & 平均" \\
\hline 標灌些等 & 13 & 15 & 13 & 11 & 13 & 15 & 10 & 12 & 18 & 16 & 15 & 13 & 16 & 16 & 15 & 蜝差率 \\
\hline $\mathrm{h}^{\circ}$ & 16 & 21 & 24 & 16 & 16 & 23 & 18 & 19 & - & 23 & 31 & 24 & 25 & 26 & 26 & \\
\hline 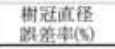 & -1 & 1 & -1 & -1 & -1 & 1 & -2 & -1 & - & 2 & 4 & -2 & 3 & -1 & -1 & $0 \%$ \\
\hline$\hat{\mathrm{h}}$ & 21 & 23 & 21 & 19 & 21 & 23 & 18 & 20 & 27 & 24 & 23 & 21 & 24 & 24 & 23 & \\
\hline 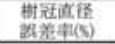 & 24 & 0 & -7 & 21 & 30 & 1 & -2 & 8 & -24 & 5 & -23 & -12 & -6 & -9 & -13 & $1 \%$ \\
\hline 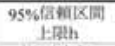 & 24 & 26 & 24 & 22 & 24 & 26 & 21 & 23 & 29 & 27 & 25 & 24 & 27 & 27 & 25 & \\
\hline 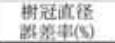 & 54 & 7 & -1 & 51 & 58 & 11 & 18 & 45 & -22 & 21 & -15 & -2 & 16 & -1 & -7 & $18 \%$ \\
\hline 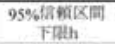 & 18 & 20 & 18 & 15 & 18 & 20 & 14 & 17 & 24 & 22 & 20 & 18 & 22 & 21 & 20 & \\
\hline 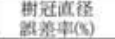 & 18 & -2 & -10 & -7 & 12 & -12 & -22 & -9 & -24 & -3 & -27 & -29 & -14 & .10 & -26 & $-10 \%$ \\
\hline
\end{tabular}

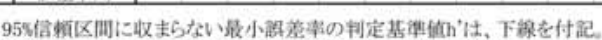

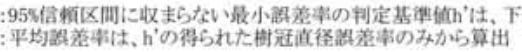

と樹冠境界累積度数は樹冠境界の情報を含む指標であることを明 らかにした。なお，樹冠境界累積度数とは空中写真画像上で樹冠 境界に当たる輝度值を求め, ヒストグラム上での輝度值のパーセ ンタイル点である。そこで，本論では画像範囲值を用いた画素毎 のパラメータの設定方法を考案するために，まず，調査区範囲に おける画像の画素值の標準偏差 SD と h' の単回帰式, および回 帰式の予測した值に対する $95 \%$ 信頼区間を示す上限式と下限式 の 3 つの式を求める。この 3 式により, それぞれ $\hat{h} を$ 求め, 最 屯平均樹冠直径との誤差率が少なく適用可能性の高い式を選定す る。次に, 樹冠として抽出された影の部分をて長情報として除去 するために，樹冠境界，すなわち影域の域值とみなすことのでき る輝度值 $\hat{\mathrm{L}}_{\mathrm{g}}$ を下記の考え方で求める。画像の標準偏差 $\mathrm{SD}$ と樹 冠境界累積度数 $\mathrm{q}_{\mathrm{g}}$ の回帰式を求め, $\mathrm{SD}$ より $\hat{\mathrm{q}}_{\mathrm{g}}$ を導出し, $\hat{\mathrm{q}}_{\mathrm{g}}$ に相 当する輝度值 $\hat{\mathrm{L}}_{\mathrm{g}}$ を求める。

最終的に，画素毎に $\hat{h}$ を計算し同質領域の計算を行い，輝度 值 $\hat{\mathrm{L}}_{\mathrm{g}}$ より暗い抽出樹冠はて長情報として除去する計算を行う。 計算結果は, 各調査区の平均樹冠直径と樹冠数の誤差率と再構成 画像を示し考察する。

\section{(4) 同質領域判定手法の解析結果の検証}

本手法による樹冠抽出の有無と精度は, 樹冠半径の大小, また, シイ・カシ萌芽林の実生木, 萌芽木, そして, 七ノキの樹冠形態 の特性により異なると想定される。そこで現地で調査した樹冠投 影図を用い以下の方法で抽出精度を明らかにする。

樹冠投影図は 2003 年 10〜11月に，デジタルコンパス付レーザー レンジファインダ，およびモバイル端末からなる森林計測システ ムを用い，不整形な測量範囲を調查区として計算機に記録した。 調查面積はシイ・カシ萌芽林が $150 \sim 625 \mathrm{~m}^{2}$ (毎木数 $26 \sim 197$ 本), ヒノキ人工林が $52 \sim 499 \mathrm{~m}^{2}$ (毎木数 $22 \sim 48$ 本) であった。調査 範囲の決定は, 画像解析や林分条件要素のデー夕を取得するに十 分な面積および本数を考慮した。樹冠投影図は，地上からの目視 により樹冠の端と思われる直下で反射鏡を移動させながらポリゴ ンデータとして記録した。毎木位置は幹・株の根元を記録すると ともに, 萌芽木の本数と, それぞれの幹直径を $1.2 \mathrm{~m}$ 高さで測定 
し検証データとした。

検証の目的は主に次の 3 点である。1つは, 適正に抽 出できる最小樹冠半径, 2 つ目は抽出樹冠と無抽出樹冠 の割合， 3 つ目は，萌芽木について抽出される樹冠が幹 毎なのか，もしくは株全体を抽出しているのかを明確化 することである。そこで，検証に用いる樹冠投影図のデー 夕は, 次の 2 つのタイプとした。1つは実生木とヒノキ であり，樹冠半径 $\mathrm{r}$ を用いる。2 2 目は萌芽木である。 萌芽木は複数の幹の上部に展開する複数の樹冠で 1 つの 萌芽木を構成している。そこで, 幹の中で最も樹冠面積 の大きい樹冠の樹冠半径 (以下, 株立樹冠半径という) r'を用いる。これは，もし幹毎に抽出されるのであれ ば，この r'が抽出されると想定したからである。なお， それぞれの幹の樹冠面積は現地調査ができなかったため, 胸高断 面積比から推定する。

次に, 画像解析により抽出された樹冠データの扱いについて述 べる。まず，抽出樹冠の中心点が樹冠投影図内に存在する，もし くは図の外に最も近接する 1 つを選び，これを抽出された樹冠と みなす。もし，図内外に抽出された樹冠がなければ，その樹冠は 解析で抽出されなかった（以下, 無抽出樹冠という) とする。な お，実生木と萌芽木は樹冠投影図内に複数の抽出樹冠が存在する 場合があり, 前者は間違った分割抽出として扱い, 後者は萌芽木 の樹冠の分割抽出とした。

最後に, シイ・カシ萌芽林は半径䛊差幅 $\mathrm{w}= \pm 1.0 \mathrm{~m}$, ヒノキ は $\mathrm{w}= \pm 0.5 \mathrm{~m}$ を適正抽出範囲と仮定し, 抽出された全ての樹冠 を適正抽出と不適正抽出に分類し適正抽出率を求める。また, 樹 冠投影図を適正／不適正で色分けして考察を行う。

\section{3. 同質領域判定手法の改良の検討}

\section{（1）標準偏差を用いた判定基準値を求める関係式の選定}

解析に使用する標準偏差 SD と推定誤差率 $0 \%$ の判定基準值 h'を表一 1 に示す。これは先の報告 ${ }^{4)}$ のデー夕を用いている。 なお，広葉樹林の No.11〜15 は h'が得られていない。これは樹 冠幅の大きい調查区であり, 大きな樹冠の検証デー夕を 1 つの樹 冠として作成した。そのため, プログラムは樹冠を分割して抽出 し誤差率が大きくなり, h’が得られなかったたためである。関係 式の作成は, 樹冠が分割されがちな老齢木や萌芽木ではなく, 可

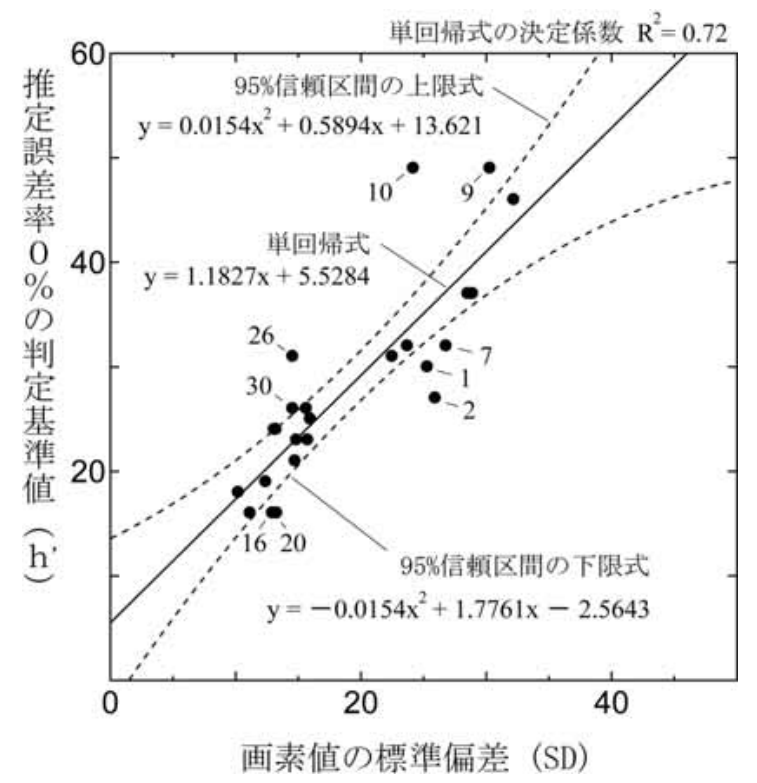

図－4 標準偏差 SD と推定誤差率 $0 \%$ の判定基準値 $\mathrm{h}^{\prime}$ の散布 図, 単回帰式, 決定係数, 95\%信頼区間の上下式
表一2 非線形回帰式により推定した樹冠境界累積度数 $\hat{\mathrm{q}}_{9}$ と 樹冠境界輝度値 $\hat{L}_{g}$

\begin{tabular}{|c|c|c|c|c|c|c|c|c|c|c|c|c|c|c|c|}
\hline No. & - & 2 & 3 & 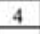 & 5 & 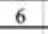 & - & 0 & 9 & 10 & 11 & 12 & 13 & 14 & 15 \\
\hline 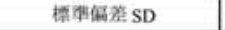 & 25 & 26 & 29 & 32 & 23 & 24 & 27 & 29 & 30 & 24 & 25 & 30 & 24 & 46 & 18 \\
\hline 粠元境界罢榬度数 $\mathrm{q}_{\mathrm{g}}$ & 11 & 18 & 18 & 9 & 8 & 20 & 5 & 20 & 9 & 18 & 9 & 8 & 10 & 7 & 12 \\
\hline 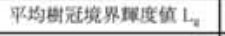 & 76 & 79 & 59 & 93 & 76 & 63 & 61 & 70 & 75 & 52 & 69 & 65 & 60 & 66 & 71 \\
\hline 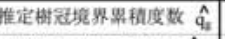 & 9 & 9 & 8 & 8 & 10 & 10 & 9 & 8 & 8 & 9 & 9 & 8 & 10 & 6 & 11 \\
\hline 推定相冠境界郎度借 $\hat{\mathrm{L}}_{\mathbf{3}}$ & 73 & 72 & 54 & 91 & 78 & 59 & 68 & 56 & 73 & 47 & 69 & 66 & 61 & 63 & 71 \\
\hline No. & 16 & 17 & 18 & 19 & 20 & 21 & 22 & 23 & 24 & 25 & 26 & 27 & 28 & 29 & 30 \\
\hline 標虾侮差 SD & 13 & 15 & 13 & 11 & 13 & 15 & 10 & 12 & 18 & 16 & 15 & 13 & 16 & 16 & 15 \\
\hline 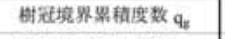 & 16 & 17 & 23 & 15 & 12 & 22 & 15 & 13 & 20 & 23 & 15 & 16 & 12 & 12 & 15 \\
\hline 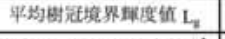 & 76 & 52 & 61 & 73 & 68 & 68 & 68 & 72 & 48 & 73 & 55 & 64 & 75 & 64 & 67 \\
\hline 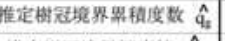 & 14 & 13 & 14 & 16 & 14 & 13 & 17 & 15 & 12 & 13 & 13 & 14 & 12 & 13 & 13 \\
\hline 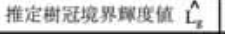 & 75 & 51 & 58 & 73 & 70 & 63 & 68 & 73 & 45 & 69 & 54 & 64 & 75 & 66 & 66 \\
\hline
\end{tabular}

能な限り実生木や若い樹木を用いることが望ましいと考えられ， 今後の課題である。ここで SD と h' の散布と単回帰式, 決定係 数，そして回帰式の予測した值に対する 95\%信頼区間の上限・ 下限式を図-4 に示す。その結果，広葉樹林の 5 調查区とスギ・ ヒノキ人工林の 4 調査区が $95 \%$ 信頼区間の範囲の外に分布した。 これらの関係式は，今後より精度の高い検証データで作成するこ とが課題である。本論では SD と h' の決定係数 0.72 というやや 相関のある結果が得られているためこれらの式を利用できると判 断した。

ここで，単回帰式と 95\%信頼区間上限・下限の式を用いて算 出した推定判定基準值 $\hat{\mathrm{h}}$ と, 樹冠直径誤差率を表 -1 に示す。 単回帰式の $\hat{h}$ の樹冠直径誤差率の平均值は, 広葉樹林が $0 \%$, スギ・ヒノキ人工林が $1 \%$ の值を示した。同質領域判定手法は, 画像の中から最大円を探し，これに重なる円をて長情報として除 去していることから，樹冠直径誤差率ができるだけ正の值になら ない式を用いる必要がある。そこで，95\%信頼区間の下限式を用 いた場合，樹冠直径の平均誤差率は広葉樹林で- $8 \%$ ， スギ・ヒ ノキ人工林で $-10 \%$ ，合わせて正の誤差率を有するのは 5 調査区 のみであった。したがって，95\%信頼区間の下限式が 3 式の内で 最屯適切に推定判定基準值 $\hat{\mathrm{h}}$ を導出できる式と判断した。

\section{（2）影域の域値に相当する樹冠境界輝度值の推定}

標準偏差 SD より影域の域值に相当する樹冠境界輝度值を推定 する関係式を導出するために，まず $\mathrm{SD}$ と樹冠境界累積度数 $\mathrm{q}_{\mathrm{s}}$ の散布図を図－5に示す。分布は， $\mathrm{q}_{\mathrm{g}}=17.5 \%$ を境に大きく 2 つ

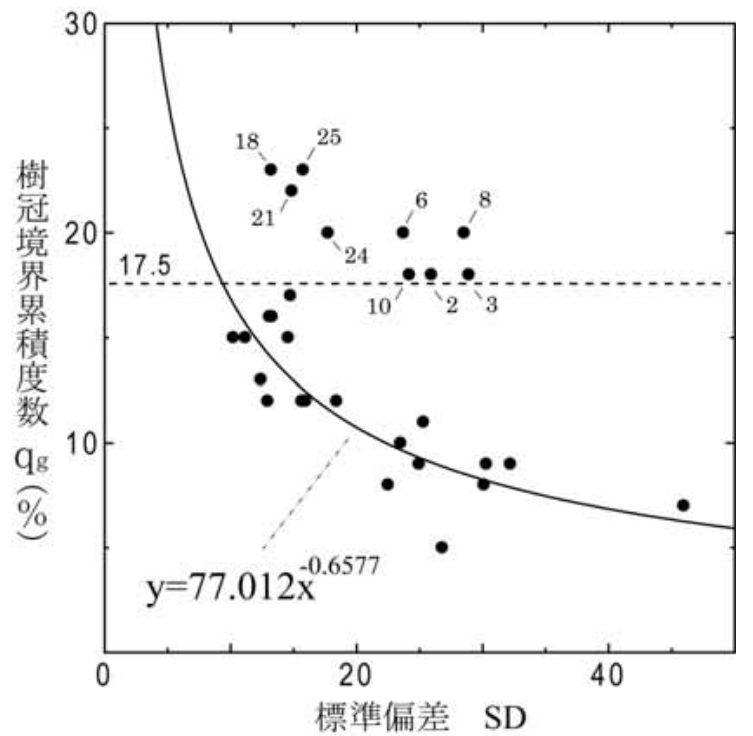

図－5＼cjkstart標準偏差 SD 亡樹冠境界累積度数 $\mathrm{q}_{9}$ の散布図 
に分かれている。図－2 の空撮画像を観察すると， $\mathrm{q}_{\mathrm{g}}>17.5 \%$ の 調查区は比較的影域が多く, 樹冠間の隙間の多い林分である。樹 冠自体の陰影に関係の無い影域が増えると, 樹冠境界を示す累積

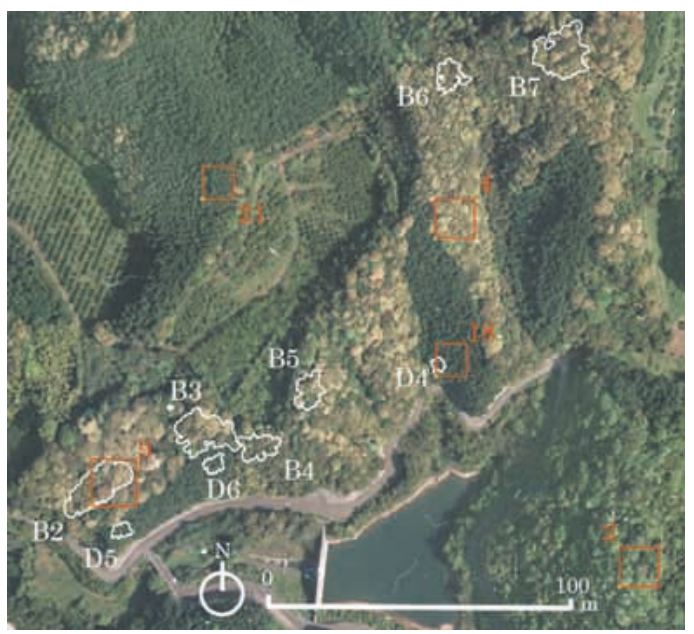

調査区周辺の空中写真（部分範囲）

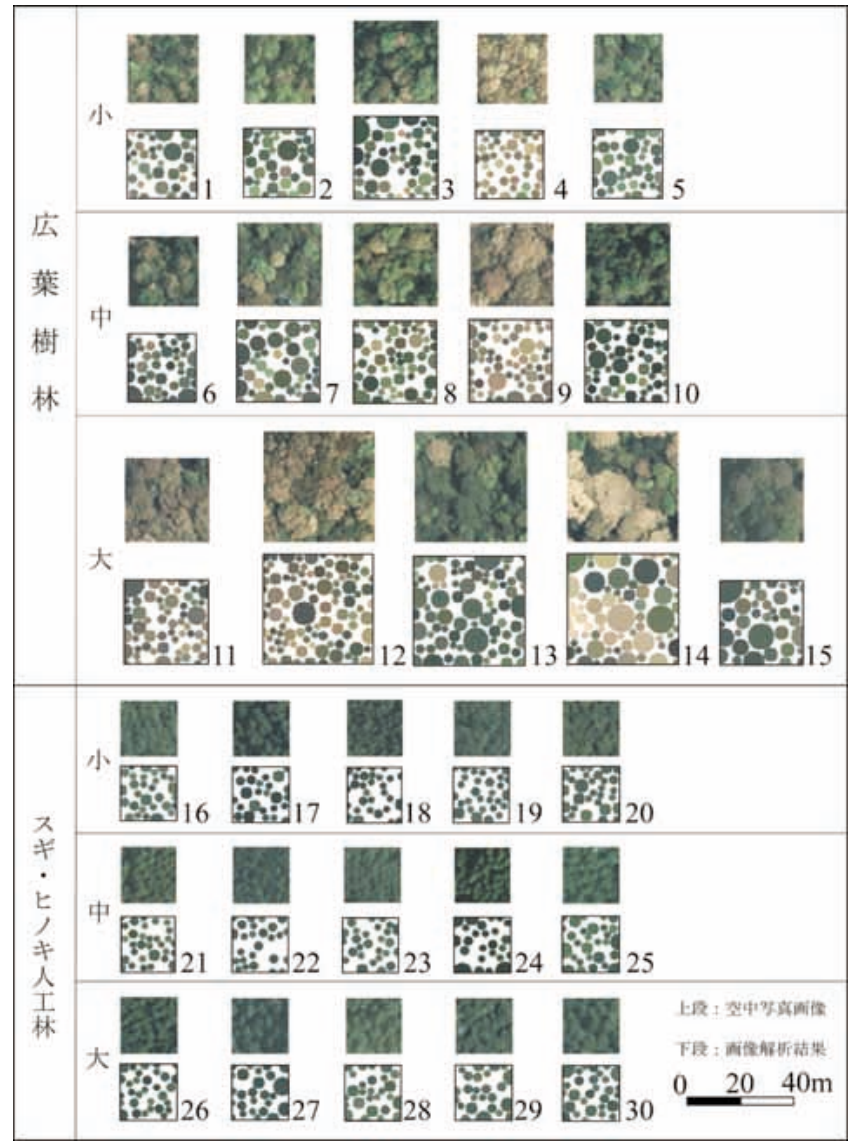

図－2 推定判定基準値 $\hat{h}$ ， と推定樹冠境界輝度値 $\complement_{g}$ を用いた解析結果

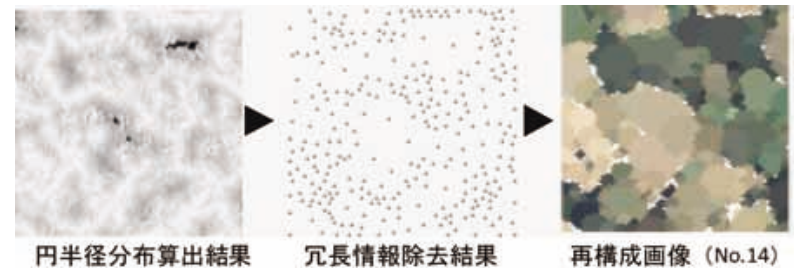

図－３小村らの同質領域判定による樹冠抽出過程
表 -3 実生木とヒノキの樹冠半径 $r$ 階別の樹冠抽出数

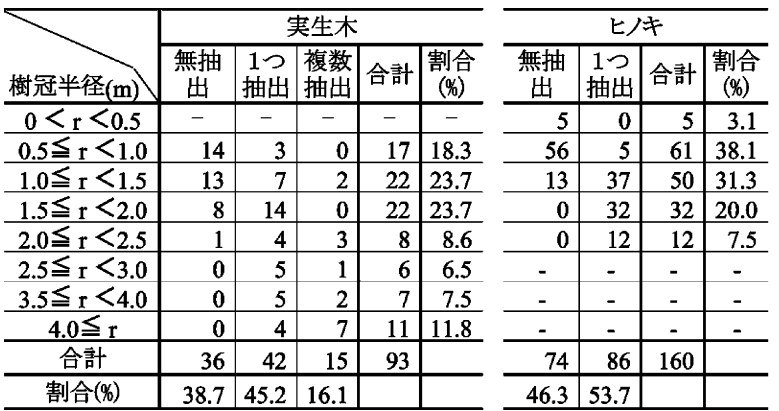

表 -4 萌芽木の株立樹冠半径 $r^{\prime}$ 階別の樹冠抽出数

\begin{tabular}{l|r|r|r|r|r}
\hline $\begin{array}{l}\text { 株立樹冠半径 } \\
r^{\prime}(\mathrm{m}) *\end{array}$ & 無抽出 & $\begin{array}{l}\text { 株抽出 } \\
\text { 樹冠 }^{* *}\end{array}$ & $\begin{array}{l}\text { 幹抽出 } \\
\text { 樹冠** }\end{array}$ & 合計 & $\begin{array}{c}\text { 割合 } \\
(\%)\end{array}$ \\
\hline $0.5 \leqq \mathrm{r}^{\prime}<1.0$ & 10 & 16 & 2 & 28 & 38.4 \\
\hline $1.0 \leqq \mathrm{r}^{\prime}<1.5$ & 4 & 12 & 2 & 18 & 24.7 \\
\hline $1.5 \leqq \mathrm{r}^{\prime}<2.0$ & 0 & 8 & 7 & 15 & 20.5 \\
\hline $2.0 \leqq \mathrm{r}^{\prime}<2.5$ & 0 & 2 & 1 & 3 & 4.1 \\
\hline $2.5 \leqq \mathrm{r}^{\prime}<3.0$ & 0 & 0 & 4 & 4 & 5.5 \\
\hline $3.0 \leqq \mathrm{r}^{\prime}<3.5$ & 0 & 0 & 3 & 3 & 4.1 \\
\hline $3.5 \leqq \mathrm{r}^{\prime}$ & 0 & 0 & 2 & 2 & 2.7 \\
\hline 合計 & 14 & 38 & 21 & 73 & \\
\hline 割合 $(\%)$ & 19.2 & 52.1 & 28.8 & & \\
\hline
\end{tabular}

*: 株立樹冠半径'`は、萌芽木内の複数の幹の中で最も樹冠面積の大きい樹冠の樹冠半径

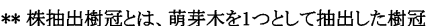

***: 幹抽出樹冠とは、萌芽木内を複数に抽出した樹冠

度数も高くなる。これらのことから，樹冠境界輝度値を推定する 関係式を求めるには， $\mathrm{q}_{\mathrm{g}}<17.5 \%$ の調査区が適切であると判断し た。ここで, SD と $\mathrm{q}_{\mathrm{g}}$ の分布に比較的フィットする非線形回帰式 を求め（図- 5 ), 式より $\hat{\mathrm{q}}_{\mathrm{g}}$ を導出し，画素值のヒストグラムよ り $\hat{\mathrm{q}}_{\mathrm{g}}$ に相当する樹冠境界輝度值 $\hat{\mathrm{L}}_{\mathrm{g}}$ を求めた（表一 2 )。

\section{(3) 同質領域判定手法の改良結果}

ここで, 同質領域判定手法の改良結果を示すために再構成画像 を図-2に，各調査区と樹冠直径と樹冠数の䛊差率（式 1 ）の散 布図を図一 6 に示す。

$($ 誤差率 $)=\frac{(\text { 解析データの平均値 })-(\text { 検証デー夕の平均値 })}{(\text { 検証 データの平均値 })} \times 100($ 式 1$)$

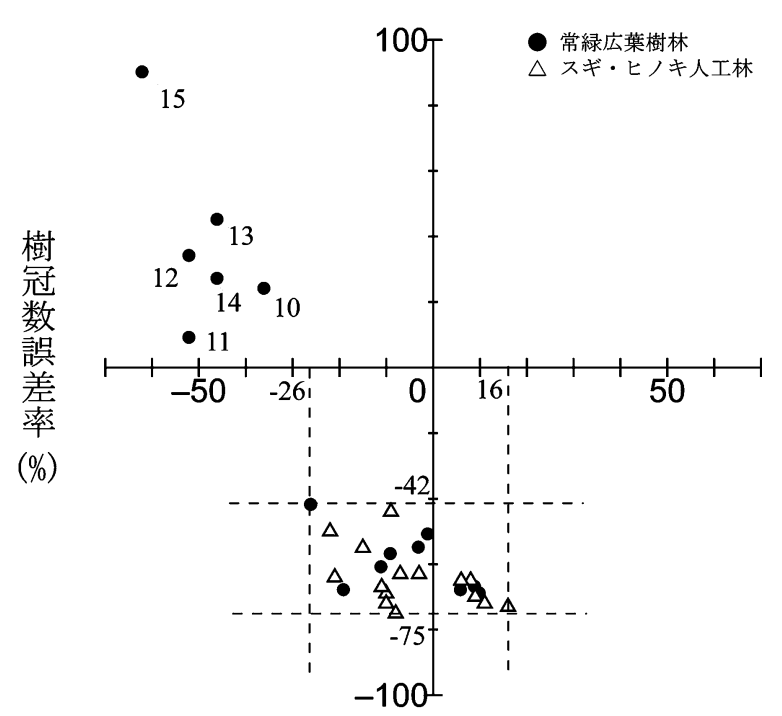

樹冠直径誤差率（\%)

図- 6 推定樹冠境界輝度值 $\hat{L}_{g}$ により影域を除去し判定基準值 $\hat{h}$ をを用いた樹冠直径・数の誤差率散布図 
これらの結果，広葉樹の樹冠大に相当するNo.10１5 を除く と, 樹冠直径の誤差率は $-26 \sim 16 \%$, 樹冠数の䛊差率は $-75 \sim-$ $42 \%$ 範囲に分布する結果が得られた。

\section{4. 同質領域判定手法の解析結果の検証}

\section{(1) 適正に抽出できる最小樹冠半径}

実生木とヒノキの抽出本数について, 樹冠半径 $\mathrm{r}$ 階別の集計表 を表一 3 に示す。実生木の抽出精度は，93 本中 36 本 (38.7\%) が無抽出で, 57 本 (61.3\%) が抽出されている。無抽出樹冠 36 本の内, 27 本 (75\%) が樹冠半径 $\mathrm{r}<1.5 \mathrm{~m}$ に集中している。一 方, 抽出された樹冠 57 本の内 45 本 (79.0\%) が樹冠半径 $r \geqq 1.5$ $\mathrm{m}$ に分布していた。このことから, 樹冠半径 $r=1.5 \mathrm{~m}$ は, 本手

表 -5 樹冠半径誤差幅 $\mathrm{w}$ 階別の抽出数と割合

\begin{tabular}{|c|c|c|c|c|c|}
\hline & \multicolumn{5}{|c|}{ シイ・カジ萌芽林 } \\
\hline $\begin{array}{l}\text { 樹冠半径 } \\
\text { 誤差幅W (m) }\end{array}$ & $\begin{array}{c}\text { 実生 } \\
\text { 木 }\end{array}$ & $\begin{array}{c}\text { 萌芽木 } \\
\text { (幹) }\end{array}$ & $\begin{array}{c}\text { 萌芽木 } \\
\text { (株) }\end{array}$ & $\begin{array}{l}\text { 合計 } \\
\text { (本) }\end{array}$ & $\begin{array}{c}\text { 割合 } \\
(\%)\end{array}$ \\
\hline $1.5 \leqq \mathrm{w}<2.0$ & 0 & 0 & 1 & 1 & 1.1 \\
\hline $1.0 \leqq w<1.5$ & 0 & 0 & 1 & 1 & 1.1 \\
\hline $0.5 \leqq w<1.0$ & 1 & 1 & 3 & 5 & 5.4 \\
\hline $0.0 \leqq \mathrm{w}<0.5$ & 0 & 8 & 6 & 14 & 15.2 \\
\hline$-0.5 \leqq w<0.0$ & 23 & 4 & 10 & 37 & 40.2 \\
\hline$-1.0 \leqq w<-0.5$ & 10 & 2 & 4 & 16 & 17.4 \\
\hline$-1.5 \leqq w<-1.0$ & 6 & 1 & 4 & 11 & 12.0 \\
\hline$-2.0 \leqq w<-1.5$ & 1 & 1 & 1 & 3 & 3.3 \\
\hline$-2.5 \leqq \mathrm{w}<-2.0$ & 0 & 0 & 0 & 0 & 0.0 \\
\hline$-3.0 \leqq w<-2.5$ & 2 & 0 & 0 & 2 & 2.2 \\
\hline$-3.5 \leqq w<-3.0$ & 2 & 0 & 0 & 2 & 2.2 \\
\hline 合計 (本) & 45 & 17 & 30 & 92 & \\
\hline 割合 $(\%)$ & 48.9 & 18.5 & 32.6 & & \\
\hline
\end{tabular}

\begin{tabular}{r|r}
\hline ヒノキ & $\begin{array}{c}\text { 割合 } \\
(\%)\end{array}$ \\
\hline 0 & 0.0 \\
\hline 1 & 1.2 \\
\hline 5 & 6.2 \\
\hline 36 & 44.4 \\
\hline 29 & 35.8 \\
\hline 10 & 12.3 \\
\hline 0 & 0.0 \\
\hline 0 & 0.0 \\
\hline 0 & 0.0 \\
\hline 0 & 0.0 \\
\hline 0 & 0.0 \\
\hline 81 & \\
\hline
\end{tabular}

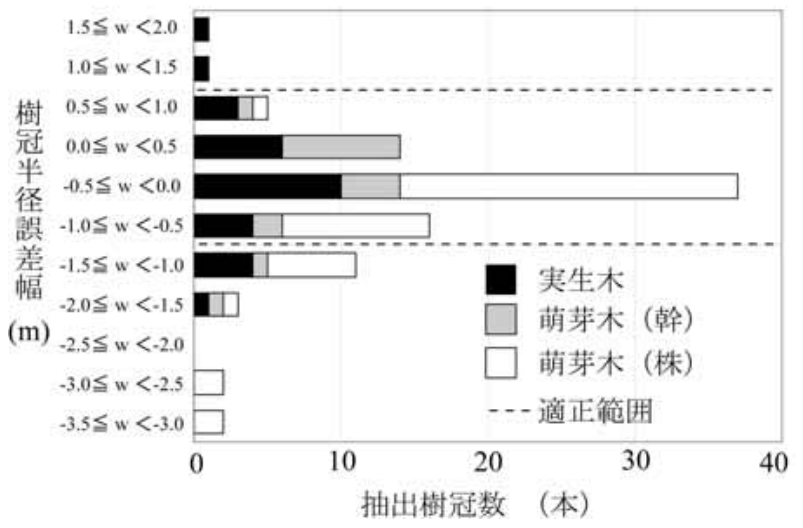

図- 7 シイ・カシ萌芽林の樹冠半径誤差幅 $w$ 別の抽出樹冠度数

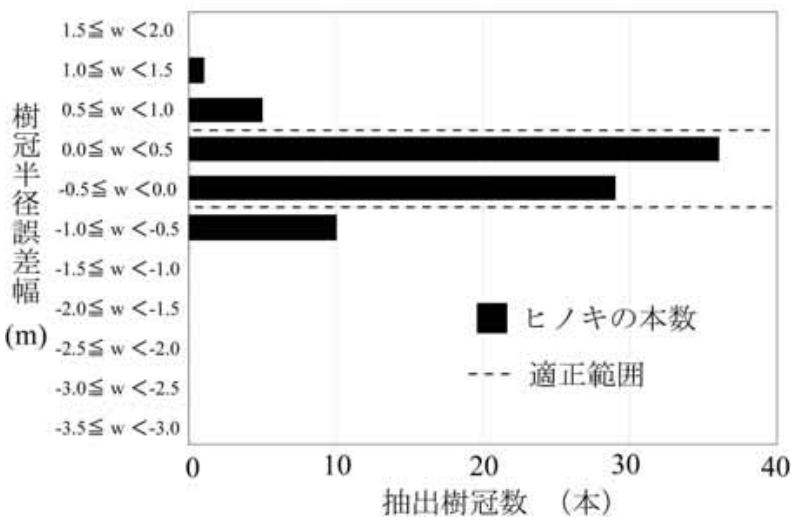

図一 8 ヒノキ人工林の樹冠半径誤差幅 $\mathrm{w}$ 別の抽出樹冠度数
法で抽出の有無を左右する域值であると考えられる。この域值は 可能性が高いというレベルであるが，本論では，以下，最小樹冠 半径という。抽出された樹冠の内, 1 本として適正に抽出された ものは 42 本 (45.2\%) で, 残りの 15 本 (16.1\%) は分割されて 抽出された。複数樹冠に抽出された実生木は, 特に樹冠半径 $r \geqq$ $4.0 \mathrm{~m}$ に多い傾向がみられた。

次に, ヒノキの抽出本数について, 樹冠半径誤差幅 $\mathrm{w}$ 階別の 集計表を表一 5 に示す。ヒノキの抽出精度は，160 本中 74 本(46. $3 \%)$ が無抽出で, 残りの 86 本 (53.7\%) が抽出された。無抽出 樹冠は全て樹冠半径 $r<1.5 \mathrm{~m}$ であり, その内 61 本（82.4\%）が $r<1.0 \mathrm{~m}$ である。抽出された樹冠は, 樹冠半径 $r \geqq 1.0 \mathrm{~m}$ が 81 本 (94.2\%) 抽出されていることから，七ノキ人工林は，樹冠半径 $\mathrm{r}=1.0 \mathrm{~m}$ が抽出の有無を左右する閾值であり, 最小樹冠半径であ ると判断した。

最後に, 萌芽木の抽出本数について, 株立樹冠半径 r' 別の集 計表を表 -4 に示す。萌芽木の抽出傾向は, 73 株中, 21 株 （28.8\%）が幹毎の樹冠を抽出，38 株（52.1\%）が株全体を樹冠 として抽出, そして 14 株（19.2\%）が無抽出であった。全体と して抽出された樹冠は 59 株（80.8\%）である。この抽出傾向を 分ける要因は, 株立樹冠半径 $r^{\prime}=1.5 \mathrm{~m}$ を境に, 株立樹冠半径 $r^{\prime}$ $<1.5 \mathrm{~m}$ であれば，無抽出，もしくは，株全体の樹冠が抽出され る傾向が認められる。逆に, 株立樹冠半径 $\mathrm{r}^{\prime} \geqq 1.5 \mathrm{~m}$ であれば, 幹毎の樹冠が抽出される傾向があると考えられた。

\section{(2) 適正抽出樹冠の分布}

樹冠の抽出を左右する域值は実生が $\mathrm{r} \geqq 1.5 \mathrm{~m}$, 萌芽木は $\mathrm{r}^{\prime} \geqq$ $1.5 \mathrm{~m}$ だと幹毎の樹冠抽出, $\mathrm{r}^{\prime}<1.5 \mathrm{~m}$ だと株全体を抽出, そして, ヒノキが $\mathrm{r} \geqq 1.0 \mathrm{~m}$ であった。この条件におけるモデルの機能性 を確認するために, 実生木, 萌芽木 (幹), 萌芽木 (株), そして ヒノキの抽出数と割合を半径誤差幅 $\mathrm{w}$ 別に, 表 -5 に示す。シ イ・カシ萌芽林の抽出精度を半径誤差幅 $\mathrm{w}= \pm 1.0 \mathrm{~m}$ とした場合, 適正抽出樹冠は $78.2 \%$ という数值が得られた。一方，ヒノキ人 工林の精度を $\mathrm{w}= \pm 0.5 \mathrm{~m}$ とした場合, 適正抽出樹冠は $80.2 \%$ で あった。これらのグラフについてシイ・カシ萌芽林を図ー 7 に, ヒノキ人工林を図 -8 に示す。いずれも, 半径誤差幅 $\mathrm{w}$ の範囲 $(-0.5 \leqq \mathrm{w}<0.5)$ が突出して多く, 前後に裙野を引く分布を示し ている。なお，本改良手法は適切な樹冠を削除しないよう小さめ に抽出するようにしたため, シイ・カシ萌芽林は $-0.5 \leqq \mathrm{w}<0.0$ が最頻値となった。これらのことから, 改良した同質領域判定手 法は, 個々の抽出精度は䛊差を含むものの, 統計的にほぼ誤差率 $0 \%$ を頂点とする度数分布が得られており, 個々の樹冠幅に応じ た樹冠抽出が行なわれているといえる。

\section{（3）全ての抽出樹冠を含めた抽出精度}

抽出された全ての樹冠を対象に, 適正抽出と不適正抽出に選別 し, 樹冠の抽出数と抽出割合を求める。シイ・カシ萌芽林の実生 木は 56 本, 萌芽木の株数は 56 株, そして, ヒノキは 144 本であっ た。その内, 萌芽木については, 抽出対象となる幹樹冠が 64 本, 株樹冠が 30 株である。これらの抽出対象木と，改良した同質領 域判定手法により抽出した全ての樹冠を用い, 適正抽出樹冠, 不 適正抽出樹冠，そして無抽出樹冠の本数と割合を表- 6 に示す。

得られた適正抽出樹冠の割合は, 実生木が $35.6 \%$, 萌芽木 （幹）が $40.6 \%$ ，萌芽木（株）が $38.9 \%$ ，そして，ヒノキが 41.4 \%であった。全体的に 35.6〜 41.4\%の結果が得られた。一方，不 適正抽出樹冠は 16.6 32.9\%存在し，無抽出樹冠は 31.5 42.0\% であった。抽出割合を平均化すると, シイ・カシ萌芽林の適正抽 出割合は $34.4 \%$, 不適正抽出割合は $22.9 \%$, 無抽出割合は 32.3 \%である。ヒノキ人工林の適正抽出割合は $41.4 \%$, 不適正抽出 割合は $16.6 \%$, 無抽出割合は $42.0 \%$ という結果となった。 
表 -6 シイ・カシ萌芽林とヒノキ人工林の適正抽出数と割合

\begin{tabular}{|c|c|c|c|c|c|c|c|c|c|c|}
\hline 実生木 & 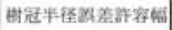 & B1 & B2 & B3 & B4 & B5 & B6 & B7 & 合計 & 制合(\%) \\
\hline 適正抽出数 & $(w \leqq \pm 1.0 \mathrm{~m})$ & 14 & 6 & $\mathrm{~T}$ & 0 & $\mathrm{~T}$ & 1 & 3 & 26 & 35.6 \\
\hline 不逼正抽出数 & $(w> \pm 1.0 \mathrm{~m})$ & 14 & 1 & I & 0 & I & 2 & 5 & 24 & 32.9 \\
\hline 無抽出数 & & 7 & $\mathbf{0}$ & 3 & 0 & 0 & 5 & 8 & 23 & 31.5 \\
\hline 荫芽木(幹) & 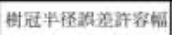 & B1 & B2 & B3 & B4 & B5 & B6 & B7 & 合尌 & 刋合 $(9)$ \\
\hline 適正抽出数 & $(w \leqq \pm 1.0 \mathrm{~m})$ & 0 & 7 & 11 & 0 & 0 & 1 & 9 & 28 & 40.6 \\
\hline 不適正抽出数 & $(w> \pm 1.0 \mathrm{~m})$ & 0 & 8 & 5 & 0 & 0 & 1 & I & 15 & 21.7 \\
\hline 無抽出数 & & 0 & 4 & 16 & 0 & 0 & 0 & 6 & 26 & 37.7 \\
\hline 蔽芽木(株) & 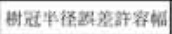 & B1 & B2 & B3 & B4 & B5 & B6 & B7 & 合計 & 辝合( $(\%)$ \\
\hline 適正抽出数 & $(w \leqq \pm 1.0 \mathrm{~m})$ & 0 & 0 & 3 & 4 & 5 & 0 & 2 & 14 & 38.9 \\
\hline 不適正抽出数 & $(w> \pm 1.0 \mathrm{~m})$ & 0 & 0 & 0 & 2 & 1 & 2 & 3 & 8 & 22.2 \\
\hline 無抽出数 & & 0 & 0 & 0 & 7 & 3 & 4 & 0 & 14 & 38.9 \\
\hline ヒ丮 & 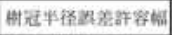 & DI & D2 & D3 & D5 & D6 & D7 & D8 & 合湖 & 㔂合(8) \\
\hline 適正抽出数 & $(w \leqq \pm 0.5 \mathrm{~m})$ & 7 & 7 & 11 & 2 & 5 & 13 & 20 & 65 & 41.4 \\
\hline 不逼正抽出数 & $(w> \pm 0.5 \mathrm{~m})$ & I & 1 & I & 3 & 0 & 6 & 14 & 26 & 16.6 \\
\hline 無抽出数 & & 15 & 12 & 14 & 0 & 4 & 6 & 15 & 66 & 42.0 \\
\hline
\end{tabular}

\section{(4) 樹冠投影図にみる不適正抽出樹冠の傾向}

不適正抽出樹冠を生じさせる原因を図一 9 に示した抽出樹冠検 証図から考察する。まず, シイ・カシ萌芽林 B1 の実生木は, 適 正に抽出されている樹冠も多いものの, 樹冠直径 $10 \mathrm{~m}$ 前後の不 整形な樹冠が分割されている状況がみられる。次に, シイ・カシ 萌芽林 B2 は, 萌芽木 (幹) について, 幹樹冠が小さめに抽出さ れるものが少なくない。シイ・カシ萌芽林 B5 は，萌芽木（株） について不整形な複数の株の樹冠群を 1 つの樹冠として抽出する 傾向が見られた。ヒノキの不適正抽出樹冠は複数の樹冠が 1 つの 樹冠と判定される状況がみられる。特に, 樹冠半径 $1 \mathrm{~m}$ 前後の樹 冠が組み合わさったときに，このような不適正抽出がみられるよ うであった。

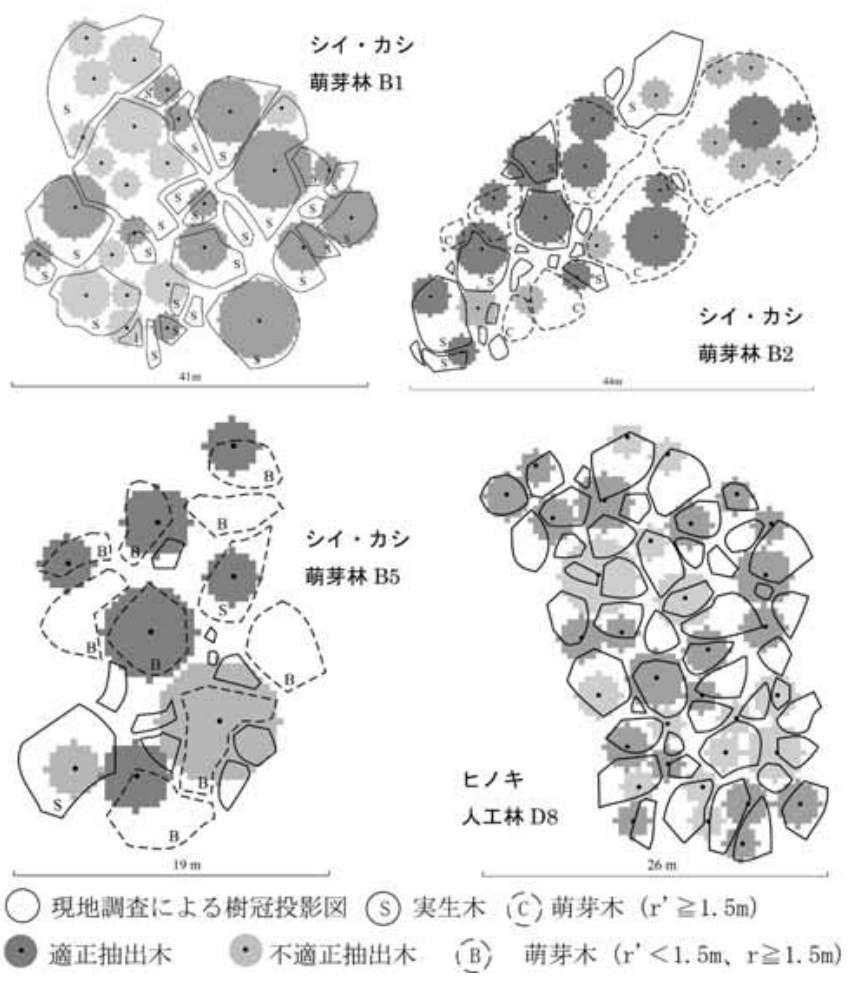

図－9 シイ・カシ萌芽林とヒノキ人工林の抽出樹冠検証図

\section{5. まとめ}

\section{(1) 本論文のまとめ}

本論文では, 福岡県福岡市近郊に分布するシイ・カシ萌芽林, およびスギ・ヒノキ人工林を対象とし, 空中写真画像を用いた樹
冠幅の抽出方法である同質領域判定手法について，画像範囲值を 用いた画素毎のパラメータの設定方法を考案し，同手法の機能性 と本対象地における樹冠抽出精度を明らかにした。本論文で得ら れた成果を以下に示す。

同質領域判定手法の改良について, 標準偏差 SD 之推定誤差率 $0 \%$ の判定基準值 h' の決定係数 0.72 という, やや相関のある関 係を利用し, SD より推定判定基準值 $\hat{\mathrm{h}}$ を導出する式として回帰 式の予測した值に対する 95\%信頼区間の下限式を選定した。ま た, SD より影域の域值に相当する樹冠境界輝度值を推定する関 係式を求めた。この結果，平均樹冠直径は $-26 \sim 16 \%$, 樹冠数は一 75〜 - 42\%の誤差率で樹冠の抽出が可能であることを示した。

次に，シイ・カシ萌芽林とヒノキ人工林を対象に改良した同質 領域判定手法を用い, 地上解像度 $45 \mathrm{~cm}$ の空中写真より抽出した 樹冠デー夕と毎木デー夕の検証を行った。適正に抽出できる最小 半径 $\mathrm{r}$ は, 実生木が $\mathrm{r}=1.5 \mathrm{~m}$ 程度, ヒノキが $\mathrm{r}=1.0 \mathrm{~m}$ 程度であっ た。萌芽木は株全体の樹冠を構成する幹の上部に展開する樹冠半 径 (株立樹冠半径) $\mathrm{r}^{\prime}<1.5 \mathrm{~m}$ の場合, 概ね株全体が抽出され, r' $\geqq 1.5 \mathrm{~m}$ の場合, 幹毎の樹冠が抽出される傾向のあることを明ら かにした。シイ・カシ萌芽林の抽出精度を樹冠半径 $\mathrm{r}< \pm 1.0 \mathrm{~m}$, ヒノキ人工林を $\mathrm{r}< \pm 0.5 \mathrm{~m}$ とした場合, 個々の樹冠は, シイ・ カシ萌芽林が $78.2 \%$ ，七ノキ人工林が $80.2 \%$ の精度で適正抽出 が行われていることを明らかにした。しかしながら, 全ての不適 正抽出樹冠と無抽出樹冠を含めると, シイ・カシ萌芽林の適正抽 出率は $34.4 \%$ ，ヒノキ人工林は $41.4 \%$ という結果が得られた。

\section{(2) 今後の課題}

空中写真画像を用いた樹冠幅の自動測定を実現させるためには, 適正に抽出できる広葉樹林の最小樹冠半径を $\mathrm{r} \leqq 1.0 \mathrm{~m}$ とし, 抽 出精度も $\mathrm{W} \pm \leqq 0.5 \mathrm{~m}$ 程度にすることが求められる。そのために は, 空中写真の地上解像度を $45 \mathrm{~cm}$ から $25 \sim 30 \mathrm{~cm}$ に変更すること が必要であると考えられる。一方で，円形でない樹冠の分割抽出 は，本手法で解決できない課題であるが， 円樹冠の適正抽出は， 使用する検証デー夕の選定と, 関係式の作成方法を洗練させるこ とにより，さらなる改善が可能であると考えられる。広葉樹林之 針葉樹林の一括抽出を考える場合, 広葉樹にみられる過度の色差 は, 関係式の一般化を難しくし, また, 抽出精度む低下させる 1 要因之考えられる。そのため, 森林の色が緑一色に染まる夏の写 真やモノクロ画像を用いて, 画像特性值である標準偏差, 樹冠境 界累積度数，ならびに，誤差率 $0 \%$ の判定基準値の関係性につい て研究を深めることが必要である。その上で, 他地域における本 モデルの検証が今後の課題である。

\section{補注及び引用文献}

1 ）小村良太郎・久保守・村本健一郎（2001）：空撮画像を用い た植生形態の定量的解析：電子情報通信学会, 信学技法 9 , 23-28

2 ) 小村良太郎・久保守・村本健一郎 (2003)：空撮画像を用い た局所フラクタル次元による樹冠解析 : 写真測量とリモート センシング 42(4), 27-37

3 ）井上光平・瀬戸島政博 - 朝廣和夫・重松敏則（2006）：多重 オルソフォト画像からの樹冠円抽出について：写真測量とリ モートセンシング 45(3), 31-36

4 ) 朝廣和夫 - 井上光平 -上原三知 - 重松敏則 - 瀬戸島政博 $(20$ 03）: 空撮画像の同質領域判定による九州北部里山林の樹冠 抽出に関する研究：ランドスケープ研究 66(5), 499-502

5 ) 朝廣和夫 -井上光平 - 重松敏則 - 瀬戸島政博 (2007) : シイ・ カシ萌芽林とヒノキ人工林の空中写真を用いた画像特性值と 林分条件要素の関係 : ランドスケープ研究 70(5), 733-736 